(C) 2018 International Journal of Nursing and Midwifery Science(IJNMS)

This is an Open Access article distributed under the terms of the Creative CommonsAttribution 4.0 International License which permits unrestricted noncommercial use, distribution, and reproduction in any medium, provided the original work is properly cited.

\title{
EFFORTS TO IMPROVE MOTHER SKILLS IN LBW (LOW BABY WEIGH) BABY CARE WITH APPROACH OF EXPERIENTIAL LEARNING CARE (ELC) METHOD.
}

\author{
HENI FRILASARI ${ }^{1}$, INDRA YULIANTI ${ }^{2}$, LASIYATI YUSWOYANI ${ }^{3}$
}

Bina Sehat PPNI health science institute Mojokerto regency East Java Indonesia

\section{Email correspondence: henifrila@gmail.com}

\section{ABSTRACT}

Keywords

Low Birth Weight Babies (LBW) are babies born with a body weight of less or equal to 2,500 grams. High levels of stress on parents, especially mothers and low levels of competency, show that parents (mothers) still have the right knowledge of caring for LBW babies. This situation affects the mother's behavior in caring for the baby. Kangaroo method is one of the rights and correct efforts to care for LBW babies because this method provides benefits to increase the temperature of LBW infants. The purpose of this study was to improve maternal skills in care for low birth weight babies with an experiential learning Care approach. The research method used queasy experimental with pre-post test design. The stages in this study start from collecting data through the mother's pre-test skills in the care of low birth weight babies, then providing midwifery interventions through Kangaroo Mother Care with the approach of Experiential Learning Care I, II and III. Next post-test was carried out; data analysis was done through Wilcoxon test with the results of $\mathrm{p}=0.003$ $<\alpha=0.05$, meaning that there was an increase in maternal skills in the care of LBW infants with the Experiential Learning Care (ELC) method. The results of this study are expected to be a guide for midwives in midwifery interventions for mothers who have LBW babies. Thus, it will be able to provide maternal skills in the care of LBW babies who are right and correct, so that mothers can care for LBW babies at home properly. 


\section{INTRODUCTION}

LBW or low birth weight babies are babies born with a body weight of less or equal to 2,500 grams (Pantiawati, 2010). Changes in body temperature in LBW need to be considered because LBW has not been able to maintain normal temperature (Sukarni, 2014). Overcoming this can be treated in infants with kangaroo methods. Usually, the temperature can be maintained between $36.5-37.5^{\circ} \mathrm{C}$. The reality method that this method of treatment is reluctant to be carried out by the mother while in the hospital. This is due to several factors. Handling provided by midwives at the hospital is considered to be sufficient and does not need to be continued at home. The LBW baby feeling of knitting will hold the baby to be the main trigger for mothers not to embrace maximally. This behavior is what makes mothers only rely on treatment and treatment from the hospital(Kristiani, 2015).

The prevalence of low birth weight babies (LBW) is estimated at $15 \%$ of all births in the world with a limit of 3.3\% $38 \%$ and is more common in developing or low socio-economic countries. Statistically, $90 \%$ of LBW events were found in developing countries, and the mortality rate was 35 times higher than in babies with birth weight of more than 2500 grams (Pantiawati, 2010). 2013 National Vulnerability Survey showed data on LBW incidence of $10.2 \%$, while in East Java reached $11.2 \%$.

A preliminary study conducted at RA Basoeni Gedeg Regional Hospital obtained data from January to December 2016 as many as 85 LBW infants, from January to December 2017 dropped to 78 babies. Based on the Preliminary Study in January 2018, 3 LBWs carried out by the kangaroo method for 120 minutes were obtained by three babies experiencing a rise in temperature, two babies experiencing an increase in pulse, and breathing improved.

Maintaining a sick or small newborn (birth weight $<2500 \mathrm{~g}$ or 37 weeks' gestation) needs to increase the body's warmth to maintain a normal temperature, hypothermia can occur quickly(Sudarti and Khoirunnisa, 2010). LBW has a central body temperature setting still in development; subcutaneous fat tissue is thinner,so that heat loss is greater, LBW is susceptible to infection so that respiratory distress syndrome and hypothermia can occur (Sukarni, 2014). Babies who experience hypothermia usually do not show symptoms of shivering because the temperature control is not perfect. This causes the initial symptoms of hypothermia are often not detected by the mother/family baby or helper. Babies who experience hypothermia are usually prone to complications, so the action that must be done immediately is to immediately warm the baby where the body of the mother and baby must be in one clothes called the kangaroo method (Sudarti and Fauziah, 2014). Clinically the kangaroo method of the baby's heartbeat is stable,and breathing is more regular so that the spread of oxygen throughout the body is better (Desmawati, 2011).

This theory has important implications for midwifery practice. Midwives seem essential to design and develop interventions that focus on mothers on LBW baby care. The purpose of this intervention is for mothers to have the right behavior in performing independent care for LBW infants after returning from the hospital. In providing midwifery care for postpartum mothers who have low birth weight babies, one of the cornerstones of thinking and can help to give the right behavior for mothers about LBW baby care 
is to use Experiential Learning Care learning methods. This method will accommodate and provide feedback and evaluation processes. Between the results of the application and what should be done.

\section{MATERIALS AND METHODS}

This study used a quasiexperimentaldesign with pre-post test design. Sampling techniques using purposive sampling. Researchers gave the stages in this study were starting from data collection through maternal behavioral pre-test on LBW baby care in the treatment and control groups, then giving midwifery intervention with experiential learning methods I, II and III while in the control group were given treatment according to the procedure hospital. Next post-test was carried out, data analysis through Wilcoxon test and the conclusion of the influence of experiential learning Care method through the kangaroo method on maternal skills in LBW baby care.

\section{RESULTS}

Table 1. Distribution of Frequency of Mother's Skills in LBW Baby Care Before the Method of Experiential Learning Care (ELC) was given at RA Basoeni Hospital, Jl. Raya Gedeg Mojokerto Regency in May-July 2018

\begin{tabular}{clcc}
\hline No & $\begin{array}{c}\text { Keterampilan Dalam } \\
\text { Perawatan Bayi BBLR }\end{array}$ & F & $\%$ \\
\hline 1 & Terampil & 4 & 26,7 \\
2 & Kurang Terampil & 11 & 73,3 \\
\hline & Jumlah & 15 & 100 \\
\hline
\end{tabular}

Based on table 5.7 it is explained that the majority of respondents were less skilled in caring for LBW babies, namely as many as 11 respondents $(73.3 \%)$.

Table 2. Distribution of Frequency of Mother's Skills in LBW Baby Care After Given the Method of Experiential Learning Care (ELC) at RSUD RA Basoeni, Jl. Raya Gedeg Mojokerto Regency in May-July 2018

\begin{tabular}{cccc}
\hline No & $\begin{array}{c}\text { Keterampilan Dalam } \\
\text { Perawatan Bayi } \\
\end{array}$ & F & $\%$ \\
\hline 0 & BBLR & & \\
\hline 1 & Kerampil & 13 & 86,7 \\
\hline & jumlah & 15 & 13,3 \\
\hline
\end{tabular}

Based on table 5.8 it is explained that most of the respondents were skilled in caring for LBW infants, namely 13 respondents $(86.7 \%)$.

Table 3. Cross Tabulation Efforts to Improve Maternal Skills in LBW Baby Care After Given the Method of Experiential Learning Care (ELC) at RA Basoeni Hospital, Jl. Raya Gedeg Mojokerto Regency in May-July 2018

\begin{tabular}{lcccccc}
\hline & \multicolumn{3}{c}{ Keterampilan } & \multicolumn{2}{c}{ Total } \\
\cline { 2 - 7 } Waktu & \multicolumn{2}{c}{ Kurang } & \multicolumn{2}{c}{ Terampil } & & \\
& Terampil & & & & \\
\cline { 2 - 7 } & $\mathrm{f}$ & $\%$ & $\mathrm{f}$ & $\%$ & $\mathrm{f}$ & $\%$ \\
\hline Pre & 11 & 73,3 & 4 & 26,7 & 15 & 100 \\
\hline Post & 2 & 13,3 & 13 & 86,7 & 15 & 100 \\
\hline Total & 13 & 43,3 & 17 & 56,7 & 30 & 100 \\
\hline
\end{tabular}

Based on table 5.9 shows that 11 respondents $(73.3 \%)$ were less skilled before being given treatment and 13 (86.7\%) after being given treatment. Based on the results of Wilcoxon's statistical test, it was found that $p=0,000<\alpha=0,05$. The 
results of data calculation using Wilcoxon statistical test found $\mathrm{p}=0.003<\alpha=0.05$.

\section{DISCUSSION}

Based on table 5.7, the majority of respondents were less skilled in treating low birth weight babies, as many as 11 respondents (73.3\%). Skills come from skilled words which means capable, capable and deft. Skills are applications of knowledge so that a person's skill level is related to the level of knowledge and knowledge (Notoadmodjo, 2010). Iverson (2001) says skills require training and the basic skills that everyone has can help to produce something more valuable more quickly. Most respondents were not skilled in providing care for low birth weight babies, so respondents were still unable to provide care for LBW infants and resulted in respondents being lazy and not patient. In the end, the respondent depends on other family members. Parents of respondents became the first oaring to fully assist in the care of low birth weight babies who had the ability and experience.

Several factors influence the lack of skilled respondents in providing care for LBW infants. Among them are work, parity, and information. Based on table 5.2 shows that most of the respondents work as housewives regarding jobs that do not get rewards, namely as many as 11 respondents (73.3\%). The profession as a housewife is a profession that has a high level of activity in the household. Homemakers always pay attention to the cleanliness and comfort that exist in the home environment so that with this busyness makes respondents rarely interact with other people. This is what causes respondents to be lacking in getting the right information about LBW baby care. Based on table 5.4 shows that most of the respondents were primipara as many as eight respondents $(53.3 \%)$.
Primipara is a woman whose first pregnancy has ended when the fetus has reached the limit of viability (Sulistyawati, 2009). Primipara respondents are new respondents who will have their first child, so they do not have good experience in giving care to LBW babies. This is why respondents become less confident and afraid to hold babies with LBW. Based on table 5.5 shows that most did not get information about deep breathing relaxation techniques as many as ten respondents $(66.7 \%)$. Information is everything that is obtained by someone both in oral and written form. Lack of information or inappropriate information causes respondents' skills in caring for LBW babies is also not appropriate. Based on table 5.8 it is explained that most of the respondents were skilled in caring for LBW infants, namely 13 respondents $(86.7 \%)$.

Based on the results of the Wilcoxon statistical test, $p=0,000<\alpha=0,05$. The results of the calculation of the data using the Wilcoxon statistical test obtained $\mathrm{p}=$ $0.003<\alpha=0.05$ means that $\mathrm{H} 1$ was received, there was an increase in maternal skills in the care of LBW infants with the Experiential Learning Care (ELC) method. Experiential Learning Care is a learning model that creates a more meaningful learning process, with what they learn. Through this model, students not only learn about mere material concepts because in this case students are directly involved in the learning process to become an experience(Hidayat, 2009).

The results of the experiential learning care learning process not only emphasize the cognitive aspects, but also are subjective in the learning process. The knowledge created from this model is a combination of understanding and transforming experiences(Choeruman, 2014). Respondents who have gained experience 
in caring for LBW babies through counseling and treatment will be able to provide a high level of memory in the respondent's memory. This is what causes respondents to have increased skills. From the less skilled to being more skilled. In addition respondents have a strong motivation in caring for LBW babies with the aim of being able to provide the best in their baby.

However, there are 2 respondents who are still not skilled in treating LBW babies. From the observation results of these respondents are still weak in points 3 and 4 . Point 3 states the hands and kai of the baby in the situation of flexion like frogs. A little more skill makes the respondent feel afraid of a broken or sore leg in the baby's leg. So that the respondent sometimes puts the baby's leg straight down. Whereas in point 4, fixation with the scarf. Respondents did the most with hesitation, making fixation tight and too loose. So that the baby feels uncomfortable.

\section{CONCLUSIONS}

From the results of research conducted Based on the results of the Wilcoxon statistical test $p=0,000<\alpha=0,05$. The results of the calculation of data $\mathrm{p}=0.003$ $<\alpha=0.05$ means that $\mathrm{H} 1$ is accepted, there is an increase in maternal skills in the care of low birth weight babies using the Experiential Learning Care (ELC) method.
Midwifery Research and Data Analysis Techniques in. Jakarta: Salemba Medika.

Kristiani, D. R. 2014. (2015). Effectiveness of the Implementation of the Kangaroo Method on Low Birth Weight Babies in the Posyandu the work area of the Selopuro Blitar Health. Http: //Www.Unibraw.Com Accessed.

Notoadmodjo. (2010). Metode Penelitian. Surabaya: Salemba Medika.

Pantiawati, I. (2010). Babies with LBW (low Birth Weight). Yogyakarta: Nuha Medika.

Sudarti and Fauziah, A. (2014). Neonatal, Infant and Toddler Child Care. Yogyakarta: Nuha Medika.

Sudarti and Khoirunnisa, E. (2010). Neonate, Infant and Toddler Childhood Midwifery Care. Yogyakarta: Nuha Medika.

Sukarni, I. and S. (2014). Pathology of Pregnancy, Childbirth, Postpartum andHigh Risk Neonates. Yogyakarta: Nuha Medika.

Sulistyawati, A. (2009). Midwifery Teaching Book on Postpartum Mothers. Yogyakarta: Andi Offset.

\section{REFERENCES}

Choeruman, S. (2014). Kangaroo Method.

Retrieved from

www.medicastore.com

Desmawati. (2011). Maternity Nursing

Intervention. Jakarta: Trans Media

Info.

Hidayat, A. A. (2009). Methods of 